\title{
David and the matriarch in the Book of Ruth
}

\author{
J.A. Loader \\ Dept. of Old Testament \\ University of South Africa \\ PRETORIA
}

\begin{abstract}
In this paper it is argued that the molif of the matriarch is not only present in the Book of Ruth, but that it also fulfils an important role. Several motifs and clusters of motifs established in the patriarchal narratives, especially that of the protection of the matriarch, are shown to be used in such a way that Ruth is portrayed as a typical matriarch. Since a matriarch is a matriarch by virtue of the importance of her offspring, the David mouf in t:17 is by no means secondary, but an inherent part of the narrative itself. This in turn has implications for the theological basis of the Davidic dynasty. Since the motif of the matriarch in this way becomes part of the royal thente, its meaning is deternined by the overarching theme of solidarity and love, viz. that the royal house is founded not on 'pure' descent, hut on solidarity and love.
\end{abstract}

\section{The problem of the 'long genealogy'}

Does David feature in the story of Ruth? This question is mooted by the scholarly discussion of the problems presented by the last six verses of the Book of Ruth. Here we find a list of David's immediate ancestors (4:17) and a genealogy which duplicates 1 Chronicles 2:5, 9-15. Whether or not the Ruth narrative addresses the lineage of King David, is not detennined merely by the relationship of the genealogy of David (4:18-22) to the rest of the book. For, even if it is secondary, we still have verse 17 to contend with.

There is widespread, but not total, agreement among Old Testament scholars that the genealogy is indeed a later addition to the narrative (cf. Eissfeldt, 1965:479480, Fohrer, 1965:269, Kaiser, 1984:196, Childs, 1979:566, Rudolph, 1962:28, Hertzberg, 1965:283, Campbell, 1978:172, Würthwein, 1969:24, Zenger, 1986: 10-11; cf., for the opposed view, Budde, 1892:43, Verhoef, 1964:114-117, and the carefully stated opinion of Sasson, 1979:232). Even Gillis Gerleman, who finds the Davidic theme the central idea around which the whole narrative was built (cf. Joon, 1924:95), shares the opinion that the genealogy is secondary (Gerleman, 1965:38). 


\section{The 'short genealogy'}

Consensus is not so wide concerning the secondary character of the verse immediately preceding the genealogy $(4: 17)$. In this verse the naming of the son born to Ruth and the lineage from him to David is given:
a. And the neighbour women called out a name for him
b. by saying, 'A son is born to Naomi!'
c. And they gave him the name Obed
d. He was the father of Jesse, the father of David.

Some scholars find the whole verse secondary (e.g. Folırer, 1965 and Zenger, 1986), others regard only the last part - that is, c-d, in which the lineage from Obed to David is given - as secondary (Würthwein, 1969; Kaiser, 1984), yet other commentators include the whole verse in the original narrative (e.g. Rudolph, 1962; Hertzberg, 1959; Gerleman, 1965; Witzenrath, 1975:24 and Sasson, 1979:177-178), while still others are unsure (e.g. Campbell, 1975). If it could be shown that at least the last half of verse 17 together with the genealogy is indeed secondary, it would mean that the narrative cannot have anything to do with the royal motif. However, if it can be shown that the story itself requires the David motif to surface in the last chapter, the opposite would be true. My purpose is not to go into the details of the problems presented by this verse (such as the issue of the naming of Obed, cf. Gunkel, 1913:84, Eissfeldt, 1965:479480 ), neither is it to discuss the genealogy. Rather, I would like to pay attention to quite another motif in the narrative, and to relate it to the question of David's lineage.

\section{The hypothesis}

My hypothesis is that the theme of the protection of the matriarch occurs at several places in the narrative, which, irrespective of whether the genealogy of 4 : 18-22 is secondary or not, necessitates of reference to King David in chapter 4. If this hypothesis can be upheld, the royal motif is to be regarded as a theme of the story itself, which, in turn, would have consequences for a theological interpretation of the Davidic dynasty.

\section{Ruth and the patriarchal narratives}

The traits shared by (the protagonist) Ruth with (female characters from) the patriarchal narratives in the Book of Genesis establish her status as a matriarch.

* Let us first consider a cluster of three related motifs: 
- Childlessness.

- The importance of offspring and an heir.

- Motherhood as a gift of God.

In the Book of Ruth all these motifs are to be found (Ruth $1: 4-5,4: 5,10,11,12$, 13). The same applies to the patriarchal narratives. Abram obtains the promise of many descendants (Gen. 12:2, 17:2, 6, 15-19, cf. 22:17) in spite of the ominous spectre of childlessness looming over him and his wife (Gen. 17:17, 18: 10-14). The motif of a large offspring is contained in the wish for Rebecca at her betrothal to Isaac (Gen. 24:60; cf. the wish for Boaz in Ruth 4:12), and the motif of childlessness applies to both Rebecca and Sarah (Gen. 25:21). In all of these cases it is Yaliweh who grants the women children (Gen. 21:1, 25:21, cf. Ruth 4:13). In the Jacob stories we encounter the same ideas once more: the matriarchs of Israel conceive because Yahweh thinks of them (Gen. 29:31, 30: 22 ), and when this happens in the case of Rachel, it terminates her childlessness (Gen. 29:31, 30:1-2, 22). The children born to them are their own, but also those bom to the slave-girls of the matriarchs are regarded as their respective children (Gen. 30:4-8, 9-13). This, again, is the motif of a son being regarded as the child of a woman who has not bom him, - a motif which is also found in the Book of Ruth (Ruth 4:17, cf. 4:16 and the idea of children being born "on the knees" of another, Gen. 30:3). The importance of offspring is a motif connected in the patriarchal narratives with the origin of Ruth's people, the Moabites (cf. Fisch, 1982:430-431). Lot's daughters express this motif in their desire to have children (Gen. 19:31-32) and, as a result of their endeavours, the patriarch of Moab is bon (Gen. 19:37).

* Another cluster of motifs occurs in association with the above-mentioned cluster:

- A famine.

- Migration to a foreign land on account of the famine.

- A sojourn in the foreign land.

These motifs are used to introduce the Ruth narrative (Ruth 1:1), which provides the setting for the opening scene. However, the sojoun motif is also represented by Ruth herself who leaves her home country to go to a land unknown to her (Ruth 1:16-18, 2:11). These motifs are firmly established in Israel's patriarchal tradition (cf. Gen. 12, 20,26,42ff) and, as such, do not only serve to colour the idyllic setting of the story in bygone times (cf. Kaiser, 1984:195), but also serve to suggest that the protagonists are comparable to the patriarchs.

* One of the patriarchal stories contains a motif which is very prominent in the Book of Ruth. In the story of Judah and Tamar (Gen. 38), the motif of the 
levirate is of central importance (cf. Fisch, 1982:429 ff. on the relationship of this story to those of Lot's daughters and Ruth). Apart from the fact that the same can be said of the Ruth story, this narrative actually refers to the Judah-Tamar episode (Ruth 4:12).

* The motif which concerns us primarily in this article, viz. that of the protection of the matriarch in danger of being violated, should also be mentioned. This motif is well attested in the narratives of Abram/Abraham and Isaac entering an unknown land. In Genesis 12 the story of Abram's migration to Egypt on account of a "famine in the land" is related; he makes his wife Sarai deny his true relationship to her by telling the untruth that she is his sister and, as a result, the matriarch finds herself in serious danger of being violated. This is averted by the interference of Yahweh who protects her against violation (Gen. 12:10-20). In Genesis 20 we find the same pattern: Abraham migrates to Gerar, personally lies about his relationship to his wife and thereby causes her to be exposed to the danger of violation. Once again God intervenes to protect the matriarch. The third narrative (Gen. 26:1-11) is about another patriarch and his wife, notably Isaac and Rebecca, but basically the same happens, although the danger of violation is realised in this instance without divine intervention (Gen. 26:10). In all three cases the motifs of migration and sojourning, and in two cases (Gen. 12 and 26) the motif of famine are associated with the danger of the matriarch being violated and her ensuing protection. All these motifs are found in the Ruth narrative, albeit not in identical relationships to each other. The passages of the Ruth narrative in which the protection of the female protagonist occurs will be highlighted in the next paragraphs.

\section{The protection of Ruth}

* The first instance is to be found in 2:8-9, where Boaz's kind treatment of Ruth is described. This is part of the fourth dialogue of the passage (vv. 8-14). By far the longest of the six conversations in the passage (the others are: vv. 2, 4, 5-7, 15-16, 19-22), it focuses attention on the two major protagonists.

Addressing Ruth as "my daughter" (v. 8), Boaz connotes goodwill towards her as well as his seniority, both in social status (cf. v. 1) and in years. He tells Ruth not to go gleaning in another field, indeed, not even to leave his field. The spelling of תע ת תעבורי occurs only three times in the Bible, here and in Exodus 18:26 and Proverbs 14:3), thereby drawing the reader's attention in the same way as the use of the nun paragogicum in חדבקין. Boaz's injunction to just stay there reminds us of 
the foreman's idea that Ruth has been acting as though Boaz's field were her home (cf. v. $7 b^{1}$ ). Moreover, there is an intensification in the advice given by Boaz: First, he advises Rutl not to go elsewhere, using the mild prohibition in Hebrew (אל, "now don't"). Then, in the second leg of his double injunction, he practically forbids her to even leave, using the Hebrew categorical prohibition (לוא [notice the plene orthography], "you must not"). Boaz is actually saying, "I want you right here". These stylistic features and the crescendo in Boaz's conduct adumbrate the protection motif in that they connote the idea that Boaz desires Ruth under his supervision.

If paternalistic (as Sasson, 1979:49 calls it), which is typical of ancient Israelite society, Boaz is doing his utmost to be kind to Ruth. In a double injunction he tells her to remain near his servant girls ( $v$. 9a; comparable to his invitation the next time he and Ruth meet, cf. 3:13). She should follow them where they work. Then another unusual and therefore prominent element is introduced. The author makes Boaz add, by way of a rhetorical question, that he has ordered the male servants not to molest her (נגע, vs. 9, often has a sexual meaning; cf. Gen. 20:6, [one of the patriarchal narratives referred to above] and Proverbs 6:29). We have not yet been given any information that Boaz has done so. In fact, he could not have given the order before speaking to Ruth, since he started speaking to her directly after the introduction provided by the overseer at his arrival. Only in verse 15 do we hear that Boaz, after the midday meal, gives orders to the workers about her treatment. This is noteworthy, since Boaz lets the relatively strange woman in on his decisions even before his staff have been informed. Her safety is so important to him that he is prepared to take unusual steps to protect her. The idea that she may be molested in another field supposes that poor women were not always safe when gleaning (cf. the same supposition in Naomi's words, v. 22). The plight of women in precarious social circumstances has never been an unknown phenomenon in the world

In this context an observation made by Campbell (1978:97) about the use of the feminine plural in עערתי (v. 8) calls for our attention. While the masculine plural is normally used to refer to the harvesters (cf. Joüon, 1924:52-53), this is the first time that the feminine plural is used to refer to the female contingent of the harvesters. Campbell considers this to be a reminder of the protection of an "'elected' woman". The fact that it is done exactly at this juncture, that is, in the context of the series of devices just discussed, renders the idea plausible. Since it is a stylistic device, it is not, as Zenger (1986:53) supposes, contradicted by verse 21 , where the more general masculine form is used. On the contrary, the fact that

1 I discuss the meaning of the last four words of Ruth 2:7 fully in an article shortly to be published in the Journal for Semtics. 
the general masculine form (including both male and female workers) is used by Ruth, while the feminine form is used by Boaz and Naomi (cf. v. 22), emphasises that they are concened about her protection while she herself is not thinking in these terms (cf. further below). Boaz is saying that it is better for Ruth's safety that she keeps company with the female workers.

* In 2:15-16 Boaz orders the male contingent of his harvesters not to harm Ruth. However, this too is not merely a straightforward command. It is structured symmetrically so as to highlight its special significance (cf. Bertman, 1965:165-168 on the author's love of symmetry): there are two pairs of injunctions, both containing an order to give Ruth preferential treatment and an order not to speak harshly to her (v. 15b [כלם] and v. 16b [ג]). The fourfold command (two pairs) addressed to the male harvesters matches the fourfold command (also two pairs) addressed to Ruth in verses $8 \mathrm{~b}-9 \mathrm{a}$. Only now does Boaz actually give the orders that he earlier claimed to have given already ( $v .9)$. Ruth may enjoy the privilege she wanted all along (cf. v. 7) - she may glean among the sheaves that are supposed to be units of just the right size for being taken away. This is not a right to which she is entitled in terms of the laws on gleaning (Lev. 19:9-10, 23:22, Deut 24:19). And that is not enough either: the reapers are required even to pull out some stalks from the bundles in their anns and drop it especially for Ruth. This too is not her right, but sheer protectionism on the part of Boaz The infinitive absolute (של neglect the instruction, and is accompanied by the second part of a twofold command not to speak harshly to Ruth. Boaz is serious enough. He could hardly have done more to show his intention to take the foreign woman under his protection. Neither could the author have done more to ensure that the readers notice it.

* The third passage in question (2:22-23) is part of the concluding dialogue of chapter 2. Naomi, without knowing it (since Ruth has not reported all the details of the day's conversations; cf. Rudolph, 1962:52), concurs with Boaz by approving that Ruth should stay with the girls in Boaz's field lest she be harmed (v. 22; cf. vv. 8-9). She uses the female נערותיו, as Boaz did in verse 8 (נערתי), thereby emphasising the polarity of the sexes, which underscores the suggestion of the danger of sexual harassment. Naomi's words of advice complete the conversation - as her advice does in 3:8. This indicates her active part in the events and their outcome. What will happen to Ruth, can at least partially be traced to her mother-in-law's participation, which includes her protection against harassment. The motif of protection is strengthened by the very fact that it is repeated several times in the chapter. However, also the unwitting concurrence of the two senior characters focuses attention on the motif. 
Campbell (1978:98) may be right that the verb פגע used by Naomi in verse 22 has been chosen to create the effect of assonance with פגע in verse 9 and therefore to underscore the danger of sexual assault to which Ruth was exposed. This, together with the other subtleties by means of which the idea of the protection of the female lead is handled in the gleaning scene, thoroughly entrenches the motif in chapter 2. Ruth appears in the same type of situation as the matriarchs of the Genesis narratives.

* The famous scene on the threshing floor (chapter 3) contains some of the most interesting examples of double entendre (cf. Bernstein, 1991:16-20) in the Bible. As I have argued in my commentary on the Book of Ruth ${ }^{2}$, there are many suggestions in the chapter with erotic overtones, and both the choice of words and the frequency of their usage enhance this effect. Suffice it here to mention Ruth's execution of Naomi's daring plan to wait until Boaz has had enough to drink and then to approach him with the right clothes and cosmetics and to get into bed with him under cover of darkness and secrecy (cf. 3:3,7). Having discussed his function גאל and Ruth's request that he marry her (vv. 9-13) and having undertaken to do for Ruth what he can in the circumstances, Boaz wants her to lie with him until morning. Here at last he tells Ruth what to do, as Naomi expected (cf. v. 4). In verse 13 he uses two verbs for this purpose, one before promising to redeem if he can, and one afterwards. The first (ליני, "stay the night") has no erotic connotations of itself (it is also used in Ruth's moving declaration of commitment to Naomi in 1:16), but the second (שכי, "lie") is again a well-known word which does not need to, but can have a sexual meaning. Accordingly, we may read Boaz's injunction that Ruth is to stay with him all night as an expression of concern implying that something may happen to her on the way home if she were to be left alone in the middle of the night. But it can also be interpreted as an invitation. Is Boaz really anxious about Ruth's safety on the way home, or would he also like to have her in his bed for the rest of the night? This makes for a highly interesting use of the protection motif: On the one hand Boaz may be seen to express his concern for Ruth's safety in that he will not allow her to walk home alone in the middle of the night. On the other hand, the question is prompted whether Boaz himself is not motivated by a desire to do to Ruth exactly what he also seems to be protecting her against. But then, again, she was asking, even pushing for it. What she wanted, is Boaz to spread his wing over her (v. 9), which can have a sexual suggestion - especially in the highly erotic context - but which also entails protecting her, notably in marriage. 
In verse 14 we hear that Ruth, naturally, does as Boaz says and spends the night with him (again the ambiguous words שכב שרגלת שב,, "lie", andeet", are used). When she leaves, she goes so early that it is still too dark for people to recognize each other. Boaz wanted no-one to know that this specific woman had come to the threshing floor. When he refers to "the woman", he cannot be speaking to Ruth herself. Neither can the words be addressed to someone else, since he desires complete secrecy. The author suggests that Boaz is muttering by himself about the night's events. What is the matter? Why the secrecy? At least part of the answer must be that he recognized the highly compromising situation that Naomi and Ruth had set up. His insistence on secrecy, therefore, has the literary effect of enhancing the suggestive character of the passage. If Boaz wishes to hide something, then obviously he has something to hide. He would not like to be suspected of taking advantage of young women in need. Thus the motif of the protection of the woman appears in a highly original garb.

* The last passage from the narrative is $4: 11-12$. These verses close the scene at the city gate $(4: 1-12)$ in which Boaz undertakes to fulfil the redeeming and levirate aspects of his function as גאל. Verses 11-12 comprise the response of the assembly which is introduced by a favourite stylistic feature of the author. In verse 9 Boaz addressed the elders and all the people, but when they reply, they are referred to in inverted order (cf., however, LXX). In this way the fact is highlighted that both groups took part in the dialogue. Their answer is quite predictable: "We are witnesses." This declaration consists of one word only: עדים. Nothing more needs to be said. The whole community will vouch for the correctness and propriety of what has transpired at the gate of Bethlehem.

However, there is more to their reply. The elders and all the townsfolk invoke a blessing of Yahweh on Boaz. They do not only obey the wishes of Boaz (cf. vv. 1-2), nor are they mere legal witnesses to his business affairs (vv. 9, 10, 1la), they also show personal affection for him. This is an emotion amply attested in the words spoken by several characters throughout the story: Naomi for her daughters-in-law and they for her as well as for their husbands (cf. 1:8-10, 16; 3:1), Boaz for Ruth (cf. 3:11; 3:14-16), the women of Bethlehem for Naomi and for Ruth (4:15). Although the storyteller never describes the inner emotions of the characters, we can infer such feelings from their words and actions (cf. the emotions of joy [which Hertzberg 1965:281 also finds in the wishes of vv. 11-12] and contentedness suggested by the words and actions described in 4:14-17). We would be justified to call our narrative the story of affection.

The wish of the Bethlehemites for Boaz has three parts: First, a wish, although addressed to Boaz, involving his new wife (v. $11 \mathrm{lb}$ ); second, a wish for Boaz himself (v. 11c); third, a wish for his house (v. 12). 
The first part (v. 11b) is clear. The people wish that Ruth may be fruitful, for they want her to be like Rachel and Leah who together built Israel. These two women were the wives of Jacob and therefore matriarchs of Israel. That they "built the house of Israel" means that the whole Israel descends from them. However, not only these two, but also their two slave-girls (who became concubines of Jacob) were involved in building the house of Israel, since the twelve tribes of Israel are descended from the four of them (Gen. 29-30). Thus the townsfolk regard the sons of Rachel and her slave-girl, Bilhah, as Rachel's children, while the sons of Leah and her slave-girl, Zilpah, count as Leah's children. This is an interesting motif, for it would seem to relate to the idea of one person's son being regarded as the child of another, which is important for understanding the levirate concept (cf. what Boaz has just said about establishing the name of the dead in this way, vv. 5, 10) and the story as a whole (cf. 4:13-17). Furthermore, the mentioning of the matriarchs reminds the reader of the matriarch theme which, as we have seen, is so prominent in chapter 2 (cf. 2:9, 21-23). If Ruth is to build the house of Israel like the matriarchs, she is to be fruitful. In the wish of the townsfolk, then, Ruth is envisaged as a matriarch, that is, she is envisaged as a mother of important descendants. Accordingly, the following passage (4:13-17) cannot relate the birth of just any child - it rather concens important offspring. The mentioning of the matriarchs in the order Rachel-Leah is noteworthy. Rachel was the younger of the two and we would expect her to be mentioned last (cf. Rudolph, 1962.69). Moreover, the Boaz family were from the tribe of Judah (cf. $4: 17$ ), one of the Leah tribes. There must be a reason for the inverted order. The prominence of Rachel relates well to the analogy between her and Ruth, notably that both were childless for a long time before they were blessed with children by Yahweh (cf. 4:13 and Gen. 30:1, 22-23).

The last part of the wish (v. 12) is also clear. It is a wish for the "house" of Boaz, that is, for his offspring. Therefore the wish too contains the idea of fruitfulness. It, moreover, parallels the first wish by another comparison to a woman from patriarchal times, thereby reinforcing the theme of the matriarch. This time reference is made to Perez (according to 4:18-22 the ancestor of Boaz) and his father, Judah. The reference is to the story told in Genesis 38 , which is important on another count as well, for it concerns an incident where the levirate is as central as it is in the Book of Ruth. This part of the wish contains an important word for deciding the interpretation of 4:18-22: it is the preposition (๖), by which Boaz's house is compared to the house of Perez. If the houses are compared, it is implied that there are two houses, while, in the genealogy, the house of Boaz is regarded as part of the house of Perez. Although it is not important for the argument I am developing, we may look upon this as evidence for the secondary character of $4: 18-22$. 
If both the first and the last parts of the blessing concern fruitfulness, it is to be expected that the wish in the middle part, for Boaz personally, would concern the same. The wish is that he will perform strongly (עסה חיל), literally make power) and bestow a name. חיל can also mean virility (cf. Job 21:7-8; Proverbs 31: 3 ), which fits our context quite well. The wish would then be that Boaz may beget children and, in synonymous parallelism, be able to name them. Such a wish is not superfluous. On the contrary, it is quite functional in the story. The wish for a numerous and significant offspring makes sense if the recipient has no children as yet. Thus the townsfolk hint at Boaz's childlessness (cf. the patriarchs Abraham and Jacob referred to above, as well as the presence of the motif in Gen. 38). This is suggestive in another sense also, because Boaz is a senior citizen (cf. the Job text just cited). And Ruth, too, has been childless for years (cf. 1:4-5). So the reader is left with another question: will these two people at last have children? Will there really be a happy ending to the story?

\section{Conclusion}

The explicit reterences to characters from the patriarchal narratives as well as the copious use of the established motifs of childlessness, levirate, the gift of a child by God, offspring and adoption (4:13-14) - all of these, read in the context of the motifs of famine, migration and sojourn, thoroughly integrate the figure of the matriarch into the fibre of the narrative itself. The picture of Ruth, then, consists of a typical migrating, childless matriarch who is exposed to danger in the land of her sojourn, but who is given protection and in the end receives a son by the grace of God. And this calls out for the final motif of the pattern to round off the picture: the son who is born must be the ancestor of important offspring. Like Sarah, Rebecca, Rachel, Leah, Tamar and even the daughters of Lot, she is to be the ancestress of a "man of consequence". And that is just what we are told in 4:17 - from the protection of this matriarch sprang King David.

If my argument is correct, this would mean that the royal theme, carried as it is by the matriarchal motif, is not only present in the Book of Ruth, it also has profound theological significance.

Often commentators look upon the theme of Moabite blood in the veins of the royal house of Israel as a dominant theme or even the dominant theme of the book (cf. Gerleman, 1965:7-11). Important it is, as we have seen. The author uses it as one of several expressions of his main theme, notably the complementarity of divine and human responsibility for events in life, showing as he does that the royal house is equally a divine and a human gift to Israel.

The important dimension, however, is that the House of David was established by covenantal loyalty, love and kindness, that is, by the pon practised by Ruth to- 
wards her mother-in-law, her late husband and the family, and not by pure descent. Kings and communities are legitimately established only by the committed solidarity of love.

Perhaps that is the cue for whoever wishes to reflect on the legitimacy and the calling of governments and nations. Perhaps it is also the cue for whoever wishes to relate the story of Ruth to the genealogy of Jesus the Son of David, the son of Jesse, the son of Obed, the son of ....

\section{Bibliography}

BERNSTEIN, M.J. 1991. Two Multivalent Readings in the Ruth Narrative Journal for the Study of the Old Testament, 50:15-26

BERTMAN, S 1965. Symmetrical Design in the Book of Ruth Journal of Biblical LiteraIure, 84:165-168

BUDDE, K 1892. Vermutungen zum Midrasch des Buches der Knige Zeitschriff fiir die altrestamentiche Wissenschaft, 12 43-46

CAMPBELL, E F 1978 Ruth A new translation with Introduction, notes and commentary Garden City: Doubleday. (The Anchor Bible)

CHILDS, B S 1979 Introduction to the Old Testament as Scripture London: SPCK

EISSFELDT, O 1965 The Old Testament - an Introduction Oxford Blackwell

FISCH, H 1982 Ruth and the Structure of Covenant History Letus Testamenum, 22 425437.

FOHRER, G 1965. Einleitung in das Alte Testament Heidelberg : Quelle \& Meyer

GERLEMAN, G 1965. Ruth Neukirchen: Neukirchener Verlag (Biblischer Kommentar)

GUNKEL, H 1913 Reden und Aufsatze Gottingen : Vandenhoeck \& Ruprecht

HERTZBERG, H.-W 1965 Die Bucher Josua, Richter, Ruth Göttingen : Vandenhoeck \& Ruprecht. (Das Alte Testament Deutsch.)

JOÜON, P 1924 [1953]. Ruth Commentaire philologique et exégétique Rome : Institut Biblique Pontifical.

KAISER, O 1984 Einleitung in das Alte Testament Gutersloh : Gerd Mohn

RUDOLPH, W 1962. Das Buch Ruth. Das Hohe Lied Die Klagelieder Gütersloh Gerd Mohn. (Kommentar zum Alten Testament.)

SASSON, J M 1979. Ruth A New Translation with a Philological Commentary and a Formalist-Folklorist Interpretation. Baltimore : Johns Hopkins University Press

VERHOEF, P A. 1964 Die genealogie van Dawid. Nederduitse Gereformeerde Teologiese Tydskrif. 5:114-117

WITZENRATH, HH 1975. Das Buch Rut. Eine Literaturwissenschaftliche Untersuchung München : Kosel

WURTHWEIN, E. 1969 Ruth (= Die funf Megillot). Tübingen : Mohr (Handbuch zum Alten Testament )

ZENGER, E 1986. Das Buch Ruth. Zürich : Evangelischer Verlag (Zürcher Bibelkommentare) 
